\title{
Surface Energy Changes Involved in Apatite Formation in Copper-Containing Bioactive Glasses
}

\author{
Camila Miranda Fonseca Duarte ${ }^{a}$, Silmara Caldas Santos ${ }^{a}$, Luana Barbosa da Cruz ${ }^{b}$, \\ Wilson Acchar ${ }^{b}$, Euler Araujo dos Santos ${ }^{a *}$ (1) \\ ${ }^{a}$ Universidade Federal de Sergipe, Departamento de Ciência e Engenharia de Materiais, 49100-000 \\ São Cristóvão, SE, Brasil. \\ ${ }^{b}$ Universidade Federal do Rio Grande do Norte, Departamento de Ciência e Engenharia de Materiais, \\ 59078-900, Natal, RN, Brasil.
}

Received: August 31, 2021; Revised: December 22, 2021; Accepted: January 24, 2022

\begin{abstract}
The aim of this work was to use the Washburn capillary rise method to evaluate changes in surface energy promoted by the insertion of $\mathrm{CuO}$ in a $58 \mathrm{~S}$ glass and its implication in bioactivity. The presence of $\mathrm{CuO}$ decreased the surface wettability by decreasing the Lewis acid-base component $\gamma_{\mathrm{S}}{ }^{\mathrm{AB}}$ and increasing the Lifshitz-van der Waals component $\gamma_{\mathrm{s}}{ }^{\mathrm{LW}}$. The insertion of $\mathrm{CuO}$ also diminished the value of the electron donor parameter $\gamma_{s} ;$; i.e., the number of negative groups. This was accompanied by a nonuniform apatite formation on the surface, likely because the presence of $\mathrm{CuO}$-rich regions with lower electron donor values impaired the adsorption of $\mathrm{Ca}^{2+}$, preventing uniform apatite precipitation. Therefore, surface energy was extremely sensitive to small physical and chemical changes in the glass structure and the behavior of the electron donor parameter could be used as an adequate probe to predict glass bioactivity.
\end{abstract}

Keywords: Washburn capillary rise, surface energy, bioactivity, bioactive glass, copper.

\section{Introduction}

Immediately upon implantation into the body, a biomaterial surface will undergo important transformations promoted by direct contact with biological fluids. These transformations are associated with dissolution, precipitation, ion exchange, and the adsorption of ions, proteins, and several other organic molecules present in the extracellular medium ${ }^{1,2}$. Living cells will reach this surface when several of these transformations have already begun, notably the protein adsorption and dissolution/precipitation processes. Therefore, surface transformations will ultimately define the bioactivity of the material and its biological efficiency ${ }^{3}$.

Among all ceramic biomaterials, bioactive glasses are the most bioactive materials, and their development has allowed great advances in the production of implants and grafts aimed at bone tissue regeneration ${ }^{4-6}$. When in contact with biological fluids, the siloxane groups ( $\mathrm{Si}-\mathrm{O}-\mathrm{Si}$ ) on the glass surface undergo hydrolysis, forming negatively charged silanol groups $(\mathrm{Si}-\mathrm{OH})$ at alkaline $\mathrm{pH}$. These negative groups attract $\mathrm{Ca}^{2+}$ ions, leading to the precipitation of a positively charged $\mathrm{Ca}^{2+}$-rich layer. This positive layer will further attract $\mathrm{PO}_{4}^{3-}$ ions, forming amorphous calcium phosphate that further crystallizes into apatite on the bioglass surface $^{6-8}$. Part of the ions involved in this process derives from the biological fluid, and another part is due the gradual dissolution of $\mathrm{Ca}$ - and $\mathrm{P}$-containing bioactive glass. The apatite layer formed on the glass surface is responsible for the high biocompatibility associated with bioactive glasses ${ }^{3}$.

*e-mail: euler@ufs.br
Along with the chemical composition, reactivity, and other parameters, surface energy is one of the driving forces involved in these surface transformations.

Several studies in the literature determine the surface energy of biomaterials, especially dense calcium phosphates and biocompatible metal alloys ${ }^{9-12}$. However, despite several authors citing the importance of surface energy to the bioactivity of glasses, little information is available about how surface energy components vary during a bioactivity assay or the exact relationship between the structure and surface energy of the glass. The morphology of the apatite coatings obtained from typical bioactivity assays prevents the use of the conventional sessile drop method for surface energy determination. The liquid drops are quickly absorbed by the porous coating, impairing contact angle measurements ${ }^{13,14}$. Conversely, the Washburn capillary rise method is specifically indicated for the measurement of contact angles in porous materials ${ }^{13-16}$. Therefore, the aim of this research was to employ the Washburn capillary rise method to measure the changes in the surface energy of $\mathrm{CuO}$-containing $58 \mathrm{~S}$ bioactive glasses $\left(58 \% \mathrm{SiO}_{2}-(33 \%-x)\right.$ $\mathrm{CaO}-x \% \mathrm{CuO}-9 \% \mathrm{P}_{2} \mathrm{O}_{5}$, wt. \%) during a bioactivity assay. This technique may be used to provide a quick method for predicting apatite formation on bioactive glasses, without effectively performing SBF assays, which normally require more time (e.g., an additional week or more).

Copper oxide $(\mathrm{CuO})$ was used to partially replace calcium oxide $(\mathrm{CaO})$ in the original $58 \mathrm{~S}$ glass composition and to intentionally promote significant differences in surface energy. Copper is an element known to effectively modify the hydrophobicity of ceramic systems ${ }^{17-19}$. In addition, 
$\mathrm{Cu}^{2+}$ is also known for its angiogenic action (stimulating vascular system formation $)^{20,21}$ and bactericidal action ${ }^{20,22,23}$ in association with biomaterials

\section{Materials and Experimental}

\subsection{Materials}

Tetraethylorthosilicate (TEOS, $\mathrm{Si}\left(\mathrm{OC}_{2} \mathrm{H}_{5}\right)_{4}$, Sigma, $>98 \%$ ), nitric acid $\left(\mathrm{HNO}_{3}\right.$ Synth, 65\%), triethyl phosphate (TEP, $\mathrm{OP}\left(\mathrm{OC}_{2} \mathrm{H}_{5}\right)_{3}$, Sigma, $\left.>99,8 \%\right)$, calcium nitrate tetrahydrate $\left(\mathrm{Ca}\left(\mathrm{NO}_{3}\right)_{2} \cdot 4 \mathrm{H}_{2} \mathrm{O}\right.$, Sigma, $\left.>99 \%\right)$, and copper nitrate trihydrate $\left(\mathrm{Cu}\left(\mathrm{NO}_{3}\right)_{2} \cdot 3 \mathrm{H}_{2} \mathrm{O}\right.$, Dinamica, $\left.>98 \%\right)$ were used in this study.

\subsection{Bioactive glass synthesis}

The sol-gel process was used to obtain $58 \mathrm{~S}$ bioactive glass $-60 \% \mathrm{SiO}_{2} \cdot 36 \% \mathrm{CaO} \cdot 4 \% \mathrm{P}_{2} \mathrm{O}_{5}(\mathrm{~mol} \%)^{24}$. Initially, $22.7 \mathrm{~mL}$ of TEOS was diluted in $48.7 \mathrm{~mL}$ of $0.1 \mathrm{~mol} / \mathrm{L}$ nitric acid $\left(\mathrm{HNO}_{3}\right)$ at room temperature. This solution was stirred for $1 \mathrm{~h}$ to ensure the complete hydrolysis and polycondensation of TEOS. Then, $4.5 \mathrm{~mL}$ of TEP and $14.31 \mathrm{~g}$ of calcium nitrate were added with a $45 \mathrm{~min}$ interval between each addition. The solution was stirred for $1 \mathrm{~h}$ and then stored in sealed plates at room temperature for 10 days to allow the gel to form.

The resulting gel was dried at $60^{\circ} \mathrm{C}$ and $120^{\circ} \mathrm{C}$ for 48 and $72 \mathrm{~h}$, respectively, for the gradual removal of water and other byproducts formed during gelation. After drying, the xerogel was ground in a planetary mill for $1 \mathrm{~h}$ at $250 \mathrm{rpm}$ and then sieved ( $80 \mathrm{mesh})$. The powder was thermally treated at $700^{\circ} \mathrm{C}$ for $1 \mathrm{~h}$ at a heating rate of $10^{\circ} \mathrm{C} / \mathrm{min}$ and stored in a dry environment for further characterization. To ensure reproducibility, three independent syntheses $(n=3)$ were performed in this work.

\subsection{Copper-containing bioactive glass synthesis}

Copper-containing bioactive glass was obtained by following the same procedure described in section 2.2, with $1 \mathrm{~mol} \%$ calcium nitrate replaced with copper nitrate. The samples were named $0 \% \mathrm{CuO}$ and $1 \% \mathrm{CuO}$ according to the copper content.

\subsection{Elemental analysis}

The composition of the obtained glass powders was determined by wavelength-dispersive X-ray fluorescence (WDXRF) with a Bruker S8-Tiger $4 \mathrm{~kW}$ spectrometer equipped with LiF 200, PET, XS-5 and XS-C crystals. The analyses were performed in a He atmosphere using the powders obtained after thermal treatment at $700^{\circ} \mathrm{C}$ for $1 \mathrm{~h}$. The relative concentration of the elements was calculated considering their respective oxides.

\subsection{Thermal analysis}

The thermal behavior of the glasses was studied by a thermogravimetric analysis and differential thermal analysis (TGA/DTA) using STA 449 F3 Jupiter equipment. Analyses were performed with approximately $60 \mathrm{mg}$ of the sample, obtained immediately after the gel was completely dried, in a $\mathrm{N}_{2}$ atmosphere with a flow rate of $50 \mathrm{~mL} / \mathrm{min}$. The samples were heated from room temperature to $950^{\circ} \mathrm{C}$ in platinum crucibles at a heating rate of $10^{\circ} \mathrm{C} / \mathrm{min}$.

\subsection{X-ray diffraction}

The glasses obtained after thermal treatment at $700^{\circ} \mathrm{C}$ were analyzed by X-ray diffraction (XRD) to confirm the glassy state of the samples. The diffraction patterns were obtained with a Shimadzu diffractometer (XRD 6000) using a $\mathrm{CuK}_{\alpha}$ source $(\lambda=1.5405 \AA)$ operated at $30 \mathrm{kV}$ and $30 \mathrm{~mA}$. The data were collected from $2 \theta$ angles of $15^{\circ}$ to $45^{\circ}$ in fixed time scanning mode ( $3 \mathrm{~s} /$ point) with a step size of $0.02^{\circ}$. The patterns were analyzed using HighScore Plus software. The standard structure used was hydroxyapatite $\mathrm{Ca}_{10}\left(\mathrm{PO}_{4}\right)_{6}(\mathrm{OH})_{2}(\mathrm{ICSD}-151414)$.

\subsection{Raman spectroscopy}

The glasses obtained after thermal treatment were analyzed by Raman spectroscopy. Spectra were recorded by using a Horiba Raman microscope (LabRAM HR Evolution). A laser emitting a wavelength of $633 \mathrm{~nm}$ was employed, and the spectra were collected with an accumulation time of $30 \mathrm{~s}$. The behavior of the bridging and nonbridging oxygens (NBOs) from silicate tetrahedra $\left(\mathrm{SiO}_{4}^{4-}\right)$ was estimated by the relative amount of $\mathrm{Q}^{\mathrm{n}}$ species obtained by deconvoluting the Raman spectra ${ }^{8}$. The curves were fit by using a multipeak Gaussian function-based approach via OriginPro software (2016). The peak positions assumed for each $\mathrm{Q}^{\mathrm{n}}$ specimen were based on the work of Sharma et al. ${ }^{25}$.

\subsection{Specific surface area}

The surface area was obtained by the Brunauer-EmmettTeller (BET) method ${ }^{26}$, and the pore volume was obtained by the Barrett-Joyner-Halenda (BJH) method ${ }^{27}$. Nitrogen adsorption analyses were carried out using Quantachrome equipment (NOVA-1200e) at $77 \mathrm{~K}$. Approximately $0.5 \mathrm{~g}$ of bioactive glass powder was degassed at $150^{\circ} \mathrm{C}$ under vacuum for $2 \mathrm{~h}$. $\mathrm{N}_{2}$ adsorption isotherms were obtained at $\mathrm{P} /$ Po range, varying from 0.05 to 0.99 .

\subsection{Bioactivity assay}

The bioactivity assay ${ }^{3,28}$ was carried out by immersing the glass powders in simulated body fluid (SBF) at a ratio of $10 \mathrm{mg} / \mathrm{mL}$ over a period of 1 and 7 days at $36.5 \pm 0.5^{\circ} \mathrm{C}$. After each time point, the suspensions were vacuum filtered, and the bioactive glass powders were dried at $120^{\circ} \mathrm{C}$ for $24 \mathrm{~h}$.

The surface transformations that occurred during immersion in SBF were followed by X-ray diffraction (under the same conditions as described in section 2.6). Morphological changes were accompanied by scanning electron microscopy (SEM) performed with a JEOL microscope (JEM-5700). Images were acquired at $5 \mathrm{kV}$ after the sample was carbon-coated with a DentonVacuum coating system (Desk V).

\subsection{Surface energy - the Washburn capillary rise method}

The contact angle of the glass surfaces, $\theta$, was calculated by using the Washburn capillary rise method before and after immersion in $\mathrm{SBF}^{13}$. This method is based on measuring the penetration rate of liquids with different and known surface energies into a capillary containing a powder material. The Washburn equation ${ }^{29}$ relates the rate of penetration with the contact angle $\theta$, as follows (Equation 1): 


$$
h^{2} / t=r \gamma_{L} \cos \theta / 2 \eta
$$

where $h$ is the height in which a liquid of a particular surface tension $\gamma_{L}$ and viscosity $\eta$ causes the liquid in the capillary to rise in a certain time, $t$. This equation can also be written as a function of the gain of mass during the rise of the liquid in the capillary, assuming the following form ${ }^{29}$ (Equation 2):

$$
w^{2} / t=c \rho^{2} \gamma_{L} \cos \theta / \eta
$$

where $w$ is the mass of a liquid with surface tension $\gamma_{L}$, density $\rho$, and viscosity $\eta$ that causes it to rise in the capillary in a certain time, $t$. In our case, the contact angle, $\theta$, was calculated by considering the gain of mass of three different liquids (water, formamide and $n$-hexane) of known Lifshitzvan der Waals component $\gamma_{\mathrm{L}}{ }^{\mathrm{LW}}$, Lewis acid-base component $\gamma_{\mathrm{L}}{ }^{\mathrm{AB}}$, total surface energy parameter $\gamma_{\mathrm{L}}^{\mathrm{T}}\left(\gamma_{\mathrm{L}}=\gamma_{\mathrm{L}}^{\mathrm{LW}}+\gamma_{\mathrm{L}}^{\mathrm{AB}}\right)$, electron acceptor parameter $\gamma_{L}{ }^{+}$, and electron donor parameter $\gamma_{\mathrm{L}}{ }^{-}$(Table 1).

The surface energy components of the bioactive glasses (solid) before and after the bioactivity assay in SBF were calculated by the van Oss-Chaudhury-Good method ${ }^{30,31}$ according to the following Equations 3 and 4:

$$
\begin{gathered}
(1+\cos \theta) \gamma_{L}=2\left(\gamma_{S}^{L W} \gamma_{L}^{L W}\right)^{1 / 2}+2\left(\gamma_{S}^{A B} \gamma_{L}^{A B}\right)^{1 / 2} \\
(1+\cos \theta) \gamma_{L}=2\left(\gamma_{S}^{L W} \gamma_{L}^{L W}\right)^{1 / 2}+2\left(\gamma_{S} \gamma_{L}^{+}\right)^{1 / 2}+2\left(\gamma_{S}^{+} \gamma_{L}^{-}\right)^{1 / 2}
\end{gathered}
$$

This theory considers that two distinct components constitute the surface energy of a solid: the Lifshitz-van der Waals interactions $\gamma_{\mathrm{S}}{ }^{\mathrm{LW}}$, and Lewis acid-base component $\gamma_{\mathrm{S}}{ }^{\mathrm{AB}}$. The first is associated with apolar or dispersive forces (van der Waals and other nonsite specific interactions between a solid surface and a liquid), and the second is associated with polar forces (hydrogen bonding, dipole-dipole, dipole-induced dipole and other site-specific interactions). In addition, this polar component is also associated with the acceptor parameter $\gamma_{\mathrm{S}}{ }^{+}$or donor parameter $\gamma_{\mathrm{S}}{ }^{-}$of the chemical groups present on the solid surface.

The statistical significance of the obtained data was evaluated by analysis of variance (ANOVA) followed by Tukey's test. Differences at $p \geq 0.05$ were considered statistically nonsignificant. The tests were performed in triplicate.

\section{Results and Discussion}

The gain of mass with respect to time for each capillary filled with the glass powder is plotted in Figure 1. As discussed in section 2.10, these curves allow us to calculate the contact angle for each liquid on each surface and the respective glass surface energy components.

The Lifshitz-van der Waals component $\gamma_{\mathrm{S}}{ }^{\mathrm{LW}}$ was higher than the Lewis acid-base component $\gamma_{S}{ }^{A B}$ in the glasses before the SBF assay, regardless of the presence of $\mathrm{CuO}$ (Figure 1). The Lifshitz-van der Waals component $\gamma_{\mathrm{S}}{ }^{\mathrm{LW}}$ represents active forces between molecules containing dipoles. Most chemical bonds in silica-based glasses have intense covalent character, which can explain these higher values. The partial replacement of $\mathrm{CaO}$ for $\mathrm{CuO}$ seemed to accentuate the covalent character since the Lifshitz-van der Waals component $\gamma_{\mathrm{S}}{ }^{\mathrm{LW}}$ increased.

The Lewis acid-base component $\gamma_{\mathrm{S}}{ }^{\mathrm{AB}}$ reflects the attraction between highly polar molecules, many times involving hydrogen bonds. In the presence of water, the sum of acid and base contributions can describe wettability. The glass with $\mathrm{CuO}$ had a lower Lewis acid-base component $\gamma_{\mathrm{s}}{ }^{\mathrm{AB}}$, suggesting a lower wettability. In fact, the water contact angles measured on the glasses with and without $\mathrm{CuO}$ were approximately $68^{\circ}$ and $53.5^{\circ}$, respectively. This means that the insertion of $\mathrm{CuO}$ in the glass structure plays a role in decreasing the polarity by decreasing the number of positive and negative groups on the surface, clearly expressed by the lower values of the electron acceptor parameter $\gamma_{\mathrm{S}}^{+}$and donor parameter $\gamma_{\mathrm{S}}{ }^{-}$.

In fact, it has been shown that copper can increase the hydrophobicity of ceramic surfaces ${ }^{17}$. Polarity reduction has been pointed out as one of the ways to reduce bacterial adhesion $^{17,18}$, which has great importance for developing antibacterial systems. However, there is a lack of information that explains how copper can effectively modify the surface tension of glasses. To answer this question, it is essential to understand how copper changes the glass structure.

The WDXRF results confirmed that approximately $1 \mathrm{~mol}$ $\% \mathrm{CuO}$ was included in the glass structure as a substitution for $\mathrm{CaO}$ (Table 2). Even this small amount of $\mathrm{CuO}$ was able to significantly change the thermal behavior of the bioactive glass (Figure $2 \mathrm{a}$ ) above $600^{\circ} \mathrm{C}$. Below $600^{\circ} \mathrm{C}$, the thermal events did not show significant differences. At approximately $120^{\circ} \mathrm{C}$, an endothermic event can be attributed to the release of physically adsorbed water and ethanol (a byproduct of TEOS hydrolysis). At approximately $300^{\circ} \mathrm{C}$, exothermic events are associated with the release of chemically adsorbed water, especially by the reaction between surface silanol groups $(\mathrm{Si}-\mathrm{OH})$ producing siloxanes $(\mathrm{Si}-\mathrm{O}-\mathrm{Si})$ and by the release of nonreacted $\mathrm{TEP}^{32}$. At approximately $500^{\circ} \mathrm{C}$, nitrate decomposition produces a strong endothermic peak ${ }^{23,33}$. Above $600^{\circ} \mathrm{C}$, the mass loss becomes insignificant, and the thermal events can be directly associated with structural phenomena,

Table 1. Density, viscosity and interfacial tensions of the liquids at $20^{\circ} \mathrm{C}$.

\begin{tabular}{lccccccc}
\hline \multirow{2}{*}{ Liquids } & \multirow{2}{*}{ Density $\mathrm{g} \mathrm{mL}^{-1}$} & \multirow{2}{*}{ Viscosity cP } & \multicolumn{5}{c}{ Surface tension $\left(\mathrm{mJ} \mathrm{m}^{-2}\right)$} \\
\cline { 3 - 8 } & & & $\gamma_{L}^{T}$ & $\gamma_{L}^{L W}$ & $\gamma_{L}^{A B}$ & $\gamma_{L}^{+}$ & $\gamma_{L}^{-}$ \\
\hline Water & 0.998 & 1.000 & 72.8 & 21.8 & 51.0 & 25.5 & 25.5 \\
\hline Formamide & 1.132 & 3.230 & 58.0 & 39.0 & 19.0 & 2.3 & 39.6 \\
\hline $\boldsymbol{n}$-Hexane & 0.663 & 0.300 & 18.4 & 18.4 & 0.0 & 0.0 & 0.0 \\
\hline
\end{tabular}


Before SBF assay
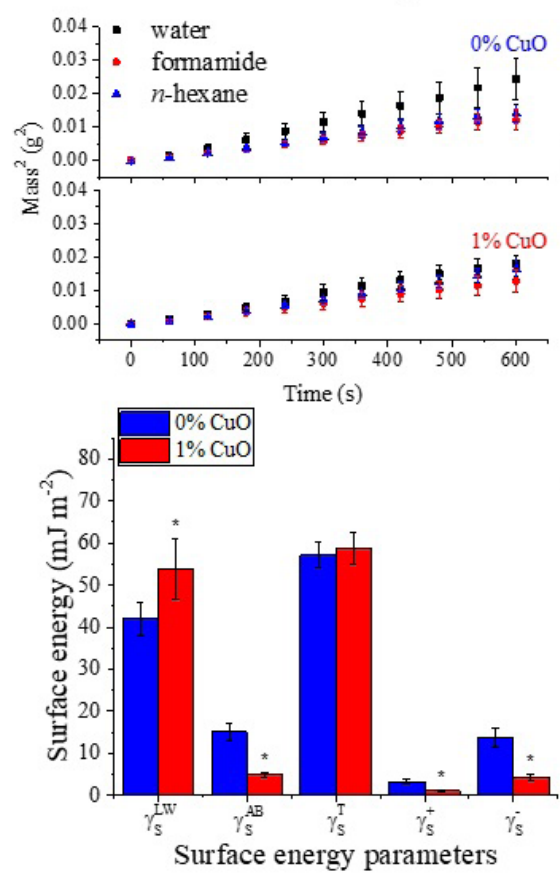

After SBF assay
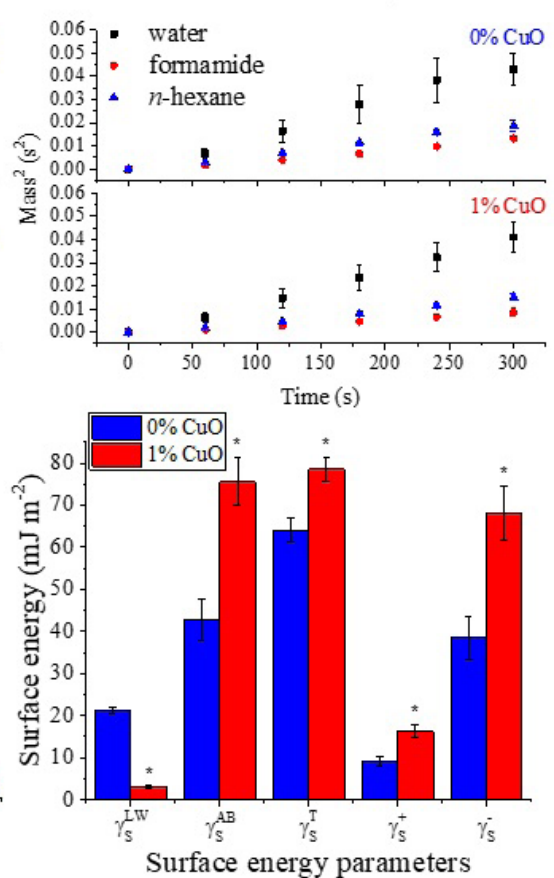

Figure 1. Average capillary rise with respect to time for three different liquids in bioactive glass powders before and after 7 days of immersion in SBF solution (top). The surface energy parameters calculated from the bioactive glasses before and after immersion in SBF solution using the Washburn capillary rise method (bottom). * Significant difference $(n=3 ; p<0.05)$ compared with the sample without CuO.

Table 2. Composition of the CuO-containing bioactive glasses obtained by wavelength-dispersive X-ray fluorescence (WDXRF).

\begin{tabular}{ccccc}
\hline \multirow{2}{*}{ Samples } & \multicolumn{5}{c}{ Composition $(\mathrm{mol} \%)$} \\
\cline { 2 - 5 } & $\mathrm{SiO}_{2}$ & $\mathrm{CaO}$ & $\mathrm{P}_{2} \mathrm{O}_{5}$ & $\mathrm{CuO}$ \\
\hline \multirow{2}{*}{$\% \mathbf{C u O}$} & $\mathbf{6 0}$ & $\mathbf{3 6}$ & $\mathbf{4}$ & - \\
\cline { 2 - 5 } & $57.83 \pm 1.34$ & $37.35 \pm 1.58$ & $4.83 \pm 0.24$ & - \\
\hline \multirow{2}{*}{$\mathbf{C u O}$} & $\mathbf{6 0}$ & $\mathbf{3 5}$ & $\mathbf{4}$ & $\mathbf{1}$ \\
& $58.80 \pm 1.59$ & $35.36 \pm 1.40$ & $4.75 \pm 0.08$ & $1.09 \pm 0.09$ \\
\hline
\end{tabular}

Lower limit of detection: $\mathrm{SiO}_{2}(175 \mathrm{ppm}) ; \mathrm{CaO}(224 \mathrm{ppm}) ; \mathrm{P}_{2} \mathrm{O}_{5}(152 \mathrm{ppm}) ; \mathrm{CuO}$ (14 ppm).

such as the glass transition temperature $\left(\mathrm{T}_{\mathrm{p}}\right)$. The insertion of $\mathrm{CuO}$ led to a $\mathrm{T}_{\mathrm{g}}$ reduction (from 673 to $648^{\circ} \mathrm{C}$ ), indicating that $\mathrm{CuO}$ acted as a network modifier in the glass structure.

Copper can be incorporated into the vitreous network in two distinct oxidation states: $\mathrm{Cu}^{2+}$ and $\mathrm{Cu}^{+}$. In both states, it is believed that its insertion leads to preferential breaking of P-O-P bonds instead of Si-O-Si bonds due to the greater affinity of copper for phosphate groups. The $\Delta_{\mathrm{i}} \mathrm{G}$ of $\mathrm{Cu}^{2+}$ $\mathrm{O}-\mathrm{P}(0.303)$ is larger than that of $\mathrm{Cu}^{2+}-\mathrm{O}-\mathrm{Si}(0.189)$ and that of $\mathrm{Cu}^{+}-\mathrm{O}-\mathrm{P}(0.449)$ relative to that of $\mathrm{Cu}^{+}-\mathrm{O}-\mathrm{Si}(0.335)^{34}$. Therefore, the $\mathrm{Cu}-\mathrm{O}$ bonds being more covalent than $\mathrm{Ca}-\mathrm{O}$ bonds induces an increasing relaxation time for the glass chains while at the same time decreasing the energy required to move those chains ${ }^{34}$. This is directly reflected in a $\mathrm{T}_{\mathrm{g}}$ reduction.

The mobility of the glass network can be explained by structural modifications in the organization of $\mathrm{SiO}_{4}^{4}$ tetrahedral units $\left(\mathrm{Q}^{n}\right)$ forming silicate chains. In $\mathrm{Q}^{n}$ structures, $n$ refers to the number of bridging oxygen (BO) atoms per silicate tetrahedron, as depicted in Figure 2b. These arrangements can be observed by Raman spectroscopy. Bands between 800 and $1100 \mathrm{~cm}^{-1}$ were attributed to the asymmetric vibration of $\mathrm{SiO}_{4}$ tetrahedra ${ }^{36}$. Within this region, the bands at 800 , 950 and $1060 \mathrm{~cm}^{-1}$ are associated with $\mathrm{Q}^{1}, \mathrm{Q}^{2}$ and $\mathrm{Q}^{3}$ silicate units, respectively ${ }^{37}$. At $960 \mathrm{~cm}^{-1}$, there is also the presence of the $\delta \mathrm{P}-\mathrm{O}$ mode of phosphate-linked species ${ }^{38}$, which in our case is masked by the predominant $v$ Si-O mode at $950 \mathrm{~cm}^{-1}$ from $\mathrm{SiO}_{2}$. $\mathrm{CuO}$ insertion led to an increase in the number of BOs in the glass structure since the relative area under the $\mathrm{Q}^{1}$ and $\mathrm{Q}^{2}$ curves diminished while $\mathrm{Q}^{3}$ increased. The reduction of $\mathrm{Q}^{1}$ and $\mathrm{Q}^{2}$ silicate units associated with the formation of more covalent $\mathrm{Cu}-\mathrm{O}-\mathrm{Si}$ bonds can explain why the Lifshitz-van der Waals component $\gamma_{\mathrm{S}}^{\mathrm{LW}}$ increased after the insertion of $1 \mathrm{~mol} \% \mathrm{CuO}$ into the glass structure. As the bonds are more covalent than ionic, the electrons in the oxygen atoms from siloxane bridges become more shielded, thus reducing the electron donor parameter $\gamma_{\mathrm{s}}{ }^{-}$of the surface groups.

The XRD patterns of the samples exhibited an amorphous profile with a halo between $20^{\circ}$ and $35^{\circ}$ (Figure 2c). Low- 
a)

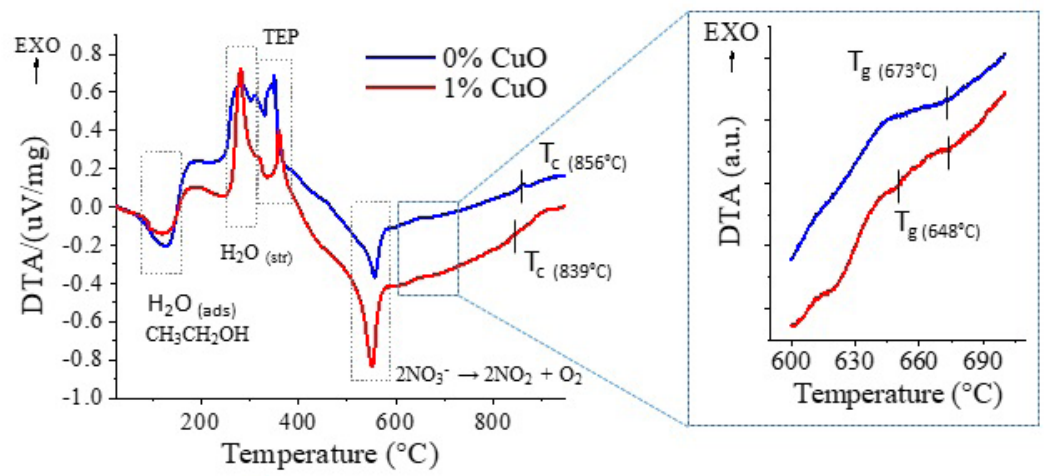

b)

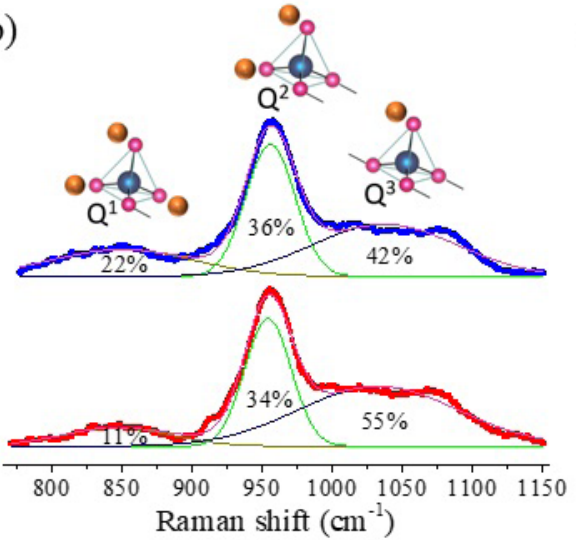

c)

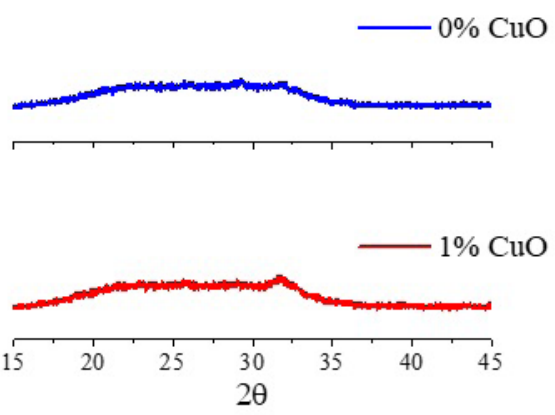

Figure 2. a) DTA curves obtained from CuO-containing bioactive glasses showing the main thermal events, the chemical changes associated with each event, crystallization temperatures, and magnified region of the glass transition temperatures. $b$ ) Raman spectra of the as-synthesized $\mathrm{CuO}$-containing bioactive glass showing the vibrational state of the main $\mathrm{Q}^{\mathrm{n}}$ silicate units and their relative areas under the curve (\%). c) XRD patterns of the as-synthesized CuO-containing bioactive glasses.

intensity and broad peaks at approximately $26^{\circ}$ and $32^{\circ}$ corresponding to a low-order hydroxyapatite phase segregated from the glass matrix as nanocrystals ${ }^{33,39,40}$ were observed in the $\mathrm{CuO}$-containing sample. TEP tends to segregate along with the modifying cations in regions around amorphous silica clusters during the sol-gel process ${ }^{39,41}$. After heat treatment, these regions can be transformed into nanocrystalline phases, such as hydroxyapatite ${ }^{39}$.

No significant changes were observed in the surface area and pore volume after the insertion of $1 \% \mathrm{CuO}$ in the glass structure. The sample without $\mathrm{CuO}$ exhibited a surface area and pore volume of $92.46 \pm 4.68 \mathrm{~m}^{2} / \mathrm{g}$ and $0.170 \mathrm{~cm}^{3} / \mathrm{g}$, respectively, while the $\mathrm{CuO}$-containing samples exhibited a surface area and pore volume of $87.30 \pm 4.66 \mathrm{~m}^{2} / \mathrm{g}$ and 0.164 $\mathrm{cm}^{3} / \mathrm{g}$, respectively. If the surface area and pore volume were not significantly altered by the presence of $\mathrm{CuO}$, surface energy parameters are even more important to explain the observed changes in apatite precipitation.

The morphology of the glass particles before the bioactivity assay in SBF (0 days) was not changed by the presence of $\mathrm{CuO}$, as shown in the SEM images (Figure 3). However, after 1 day of immersion in SBF, the glass surfaces were coated by a layer of globular particles distributed across the surface. XRD analyses (Figure 4) showed the formation of important peaks at approximately $25.9^{\circ}$ and $31.8^{\circ}$ that are typical of the (0 0 2), (2 11 l $),\left(\begin{array}{lll}1 & 1 & 2\end{array}\right)$ and (3 000$)$ hydroxyapatite planes $s^{42,43}$.
The presence of these peaks confirmed the formation of a hydroxyapatite phase typically observed in biomineralization assays using $\mathrm{SBF}^{3,39}$. The same peaks were found in the $\mathrm{CuO}$ containing sample at days 1 and 7 . However, in this sample, the area under the amorphous halo observed at approximately $22^{\circ}$ compared with the area under the crystalline peaks was larger than in the sample without $\mathrm{CuO}$ (Figure 4), especially after 7 days of immersion. This indicates that the coating was thinner or did not cover the entire glass surface completely. In fact, SEM images showed uncoated areas on the CuOcontaining sample (Figure 3, yellow arrows), explaining the higher amount of amorphous phase on these samples. This behavior substantiated the inhibitory effect of $\mathrm{CuO}$ on the glass surface reactivity and, consequently, on hydroxyapatite formation (bioactivity).

The inhibitory effect of $\mathrm{CuO}$ on apatite formation can be attributed to the changes in surface energy, directly caused by the structural rearrangements shown previously. One could assume that the decrease in the electron donor parameter $\gamma_{\mathrm{s}}{ }^{-}$of the surface by the presence of $\mathrm{CuO}$ impaired the adsorption of $\mathrm{Ca}^{2+}$, further preventing the capture of $\mathrm{PO}_{4}^{3-}$ and formation of calcium phosphate clusters on the surface. This seems true because the $\mathrm{CuO}$-containing glass surface becomes even more negative after immersion. Conversely, the sample without $\mathrm{CuO}$ became less negative after immersion, indicating that the negative charges were neutralized by 

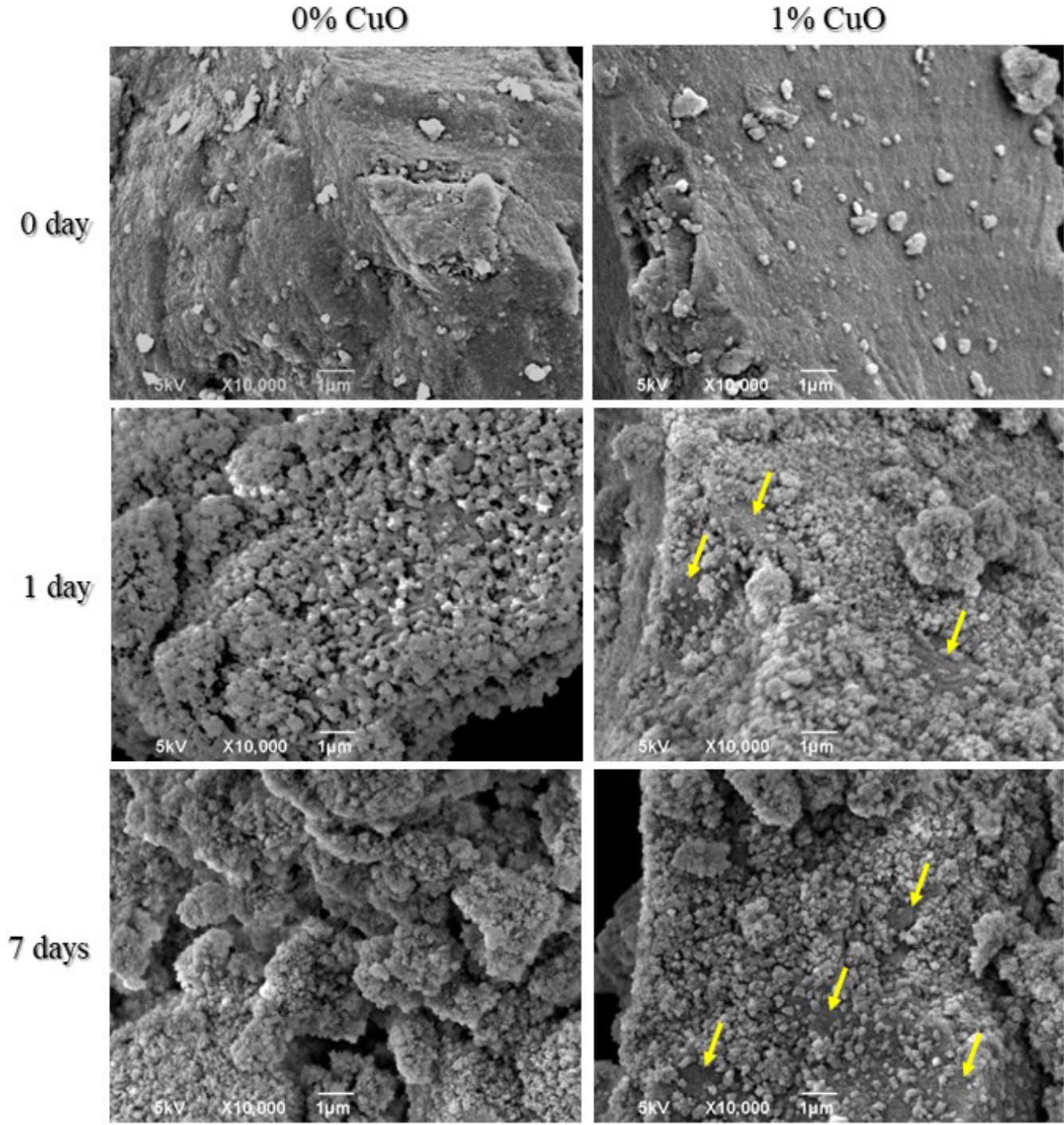

Figure 3. SEM images of the bioactive glass samples before ( 0 day or before the SBF assay) and after 1 and 7 days of immersion in SBF. Low-order hydroxyapatite nanocrystals coating the surfaces are observed after immersion in SBF. Yellow arrows show uncoated regions on the $\mathrm{CuO}$-containing samples.

adsorbing $\mathrm{Ca}^{2+}$ from the $\mathrm{SBF}$, with the consequent formation of a surface hydroxyapatite layer after the incorporation of $\mathrm{PO}_{4}^{3-}$ groups. It has been demonstrated that an increase in the hydrophilicity (polar component) of treated titanium surfaces ${ }^{44}$ promotes apatite precipitation ${ }^{45}$. Indeed, the polar component $\gamma_{\mathrm{s}}^{\mathrm{AB}}$ measured on the samples without $\mathrm{CuO}$ was larger than that observed on the $\mathrm{CuO}$-containing samples. Nevertheless, the inhibitory effect of copper ions on apatite formation must also be considered.

Several ions are known to inhibit apatite precipitation in aqueous media ${ }^{43,46}$. In general, these ions tend to avoid the nucleation of calcium clusters at the beginning of the precipitation process or further apatite crystallization. In any case, inhibition occurs along with significant morphological changes in the hydroxyapatite crystals ${ }^{43}$. The average crystallite sizes calculated for the $\left[\begin{array}{lll}0 & 0 & 1\end{array}\right]$ crystal direction, i.e., the $\left(\begin{array}{lll}0 & 0 & 2\end{array}\right)$ plane of hydroxyapatite, did not show significant differences between the samples with and without $\mathrm{CuO}$ (Figure 4). This means that the amount of copper ions in the solution was not enough to promote substantial disorder in the lattice, thus decreasing the crystallite size, as expected for $\mathrm{Cu}$-doped hydroxyapatite phases ${ }^{47}$.

The uncoated regions observed on the $\mathrm{CuO}$-containing bioglass in the SEM images (Figure 3) could reflect the heterogeneous distribution of copper and phosphate along the glass structure, as discussed before. The previous presence of $\mathrm{CuO}$-rich regions across the glass structure might have generated regions with a very lower electron donor value. In these regions, hydroxyapatite precipitation during the SBF assay was avoided because of the small attraction of $\mathrm{Ca}^{2+}$ ions to the surface, as depicted in Figure 5. In adjacent regions with higher electron donor values, calcium phosphate clusters could be formed. 


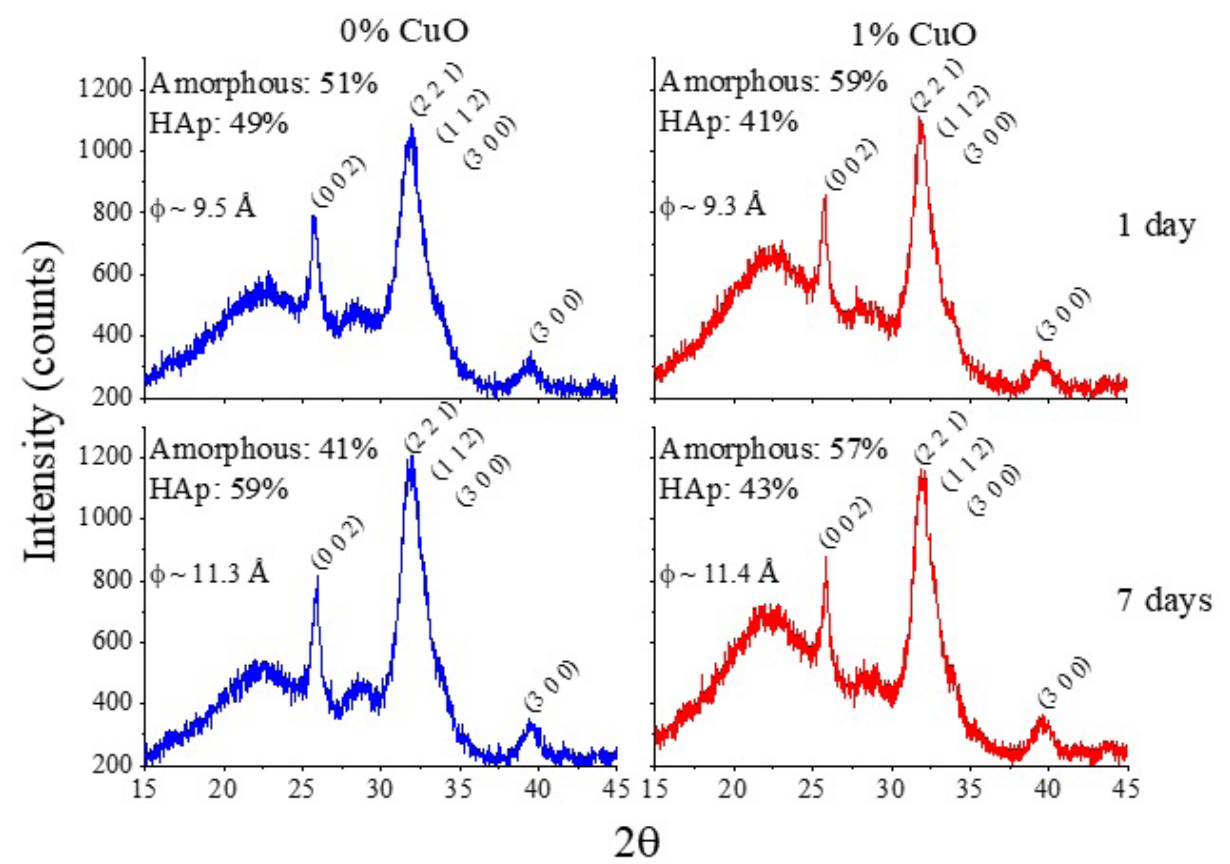

Figure 4. XRD data for the CuO-containing bioactive glasses after immersion in SBF for 1 and 7 days. The relative area (\%) under the glass amorphous curve (approximately $22^{\circ}$ ) and the main crystalline diffraction peaks from hydroxyapatite are shown. The average crystallite size $(\Phi)$ estimated by the Scherrer equation along the $\left[\begin{array}{lll}0 & 0 & 1\end{array}\right]$ direction is stated for each condition.
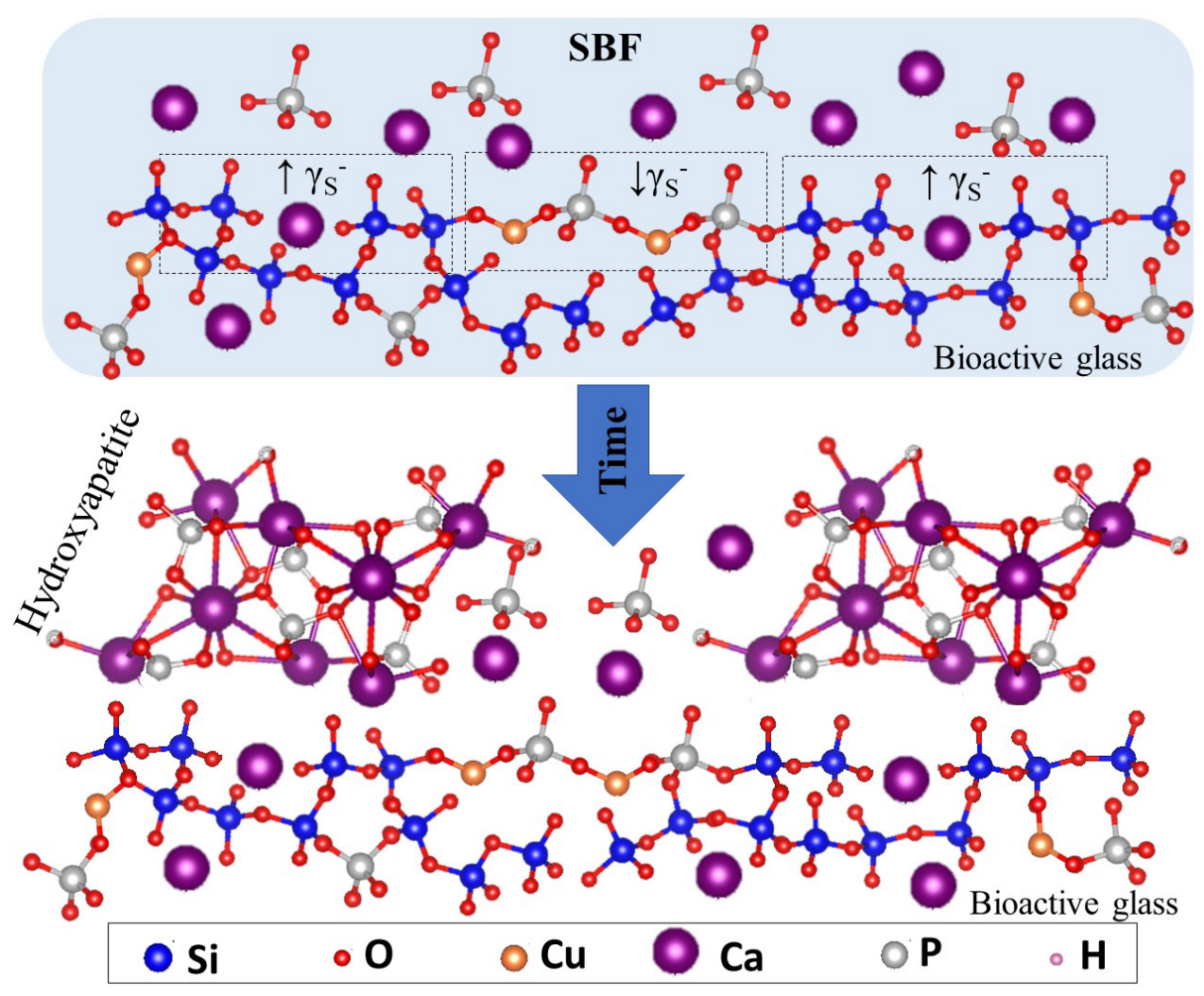

Figure 5. Schematic illustration of hydroxyapatite precipitation on $\mathrm{CuO}$-containing bioactive glasses. The $\mathrm{Cu}-\mathrm{O}-\mathrm{P}$ bonds are more covalent than the Ca-O-P bonds, which yield regions with lower electron donor parameter values. These regions weakly attract $\mathrm{Ca}^{2+}$ ions and, consequently, are less susceptible to hydroxyapatite precipitation. 
Because of its modifying nature, copper is known to interfere not only with the dissolution of vitreous systems ${ }^{22,23}$ but also with apatite precipitation ${ }^{43,46}$. Although there were no copper ions in the SBF, the inherent dissolution of the glass led to the release of these ions during the assay. The slight decrease in $\mathrm{T}_{\mathrm{g}}$ observed for the $\mathrm{CuO}$-containing samples suggested that they experienced increased dissolution as well. Therefore, one could assume that a higher degree of dissolution interfered with the coating process and added to the copper inhibitory character promoted by these changes in surface energy.

These results suggest that the Washburn capillary rise method can be very useful to follow the surface energy changes in bioactive glass systems during bioactivity assays. The surface energy was extremely sensitive to small physical and chemical changes in the glass structure, and the behavior of the electron donor parameter could be directly associated with the degree of apatite formation on the surface. This specific parameter of surface energy seems to be an adequate probe to anticipate the bioactive glass behavior in SBF assays, i.e., bioactivity.

\section{Conclusion}

The insertion of $\mathrm{CuO}$ into the glass structure decreased the glass transition temperature and crystallization temperature. The $\mathrm{Cu}-\mathrm{O}$ bonds being more covalent than the $\mathrm{Ca}-\mathrm{O}$ bonds increased the amount of $\mathrm{Q}^{2}$ and $\mathrm{Q}^{3}$ silicate units and decreased the energy required to move silicate chains. The presence of $\mathrm{CuO}$ diminished the surface wettability by means of a considerable drop in surface polarity $\gamma_{\mathrm{S}}{ }^{\mathrm{AB}}$ and a rise in the Lifshitz-van der Waals component $\gamma_{\mathrm{S}}{ }^{\mathrm{LW}}$. In general, the electron donor parameter of the surface energy $\gamma_{S}{ }^{-}$was higher than the electron acceptor parameter $\gamma_{\mathrm{S}}^{+}$, confirming the predominance of negative groups on surfaces. However, the insertion of $\mathrm{CuO}$ into the glass structure remarkably diminished the number of negative groups on the surface. This behavior was accompanied by the presence of uncoated regions after the SBF assay. In this case, the presence of $\mathrm{CuO}$-rich regions decreased the electron donor parameter of the surface, preventing the adsorption of $\mathrm{Ca}^{2+}$ ions necessary to form the apatite layer in the SBF assay. Therefore, the electron donor parameter seems to be an adequate probe to predict the bioactivity behavior of bioactive glasses.

\section{Acknowledgments}

The authors acknowledge financial support from the Brazilian research agencies CNPq, FAPITEC/SE and CAPES in the form of the grant PROMOB CAPES/FAPITEC-SE ( $\left.N^{\circ} 88881.157913 / 2017-01\right)$. The authors are also grateful to the Federal University of Rio Grande do Norte for the Raman spectroscopy analyses.

\section{References}

1. Liu Z, Liu X, Ramakrishna S. Surface engineering of biomaterials in orthopedic and dental implants: strategies to improve osteointegration, bacteriostatic and bactericidal activities. Biotechnol J. 2021;16(7):e2000116. http://dx.doi.org/10.1002/ biot.202000116. PMid:33813785.
2. Liu Z, Liu X, Ramakrishna S. Surface engineering of biomaterials : optimizing interactions between biomaterials and host tissues and organs. Authorea. 2020:1-18. In press. https://doi.org/10.22541/ au.159050434.46231599.

3. Kokubo T, Takadama H. How useful is SBF in predicting in vivo bone bioactivity? Biomaterials. 2006;27(15):2907-15. http:// dx.doi.org/10.1016/j.biomaterials.2006.01.017. PMid:16448693.

4. Zheng K, Boccaccini AR. Sol-gel processing of bioactive glass nanoparticles: a review. Adv Colloid Interface Sci. 2017;249:363-73. http://dx.doi.org/10.1016/j.cis.2017.03.008. PMid:28364954.

5. Lopes JH, Fonseca EMB, Mazali IO, Magalhães A, Landers $\mathrm{R}$, Bertran CA. Facile and innovative method for bioglass surface modification: optimization studies. Mater Sci Eng C Mater Biol Appl. 2017;72:86-97. http://dx.doi.org/10.1016/j. msec.2016.11.044. PMid:28024643.

6. Jones JR. Reprint of: review of bioactive glass: from Hench to hybrids. Acta Biomater. 2015;23(Suppl.):S53-82. http://dx.doi. org/10.1016/j.actbio.2015.07.019. PMid:26235346.

7. Santos SC, Barreto LS, Santos EA. Nanocrystalline apatite formation on bioactive glass in a sol-gel synthesis. J NonCryst Solids. 2016;439:30-7. http://dx.doi.org/10.1016/j. jnoncrysol.2016.02.013.

8. Santana LAB, Oliveira PH Jr, Damia C, Tavares DS, Santos EA. Bioactivity in SBF versus trace element effects: the isolated role of $\mathrm{Mg} 2+$ and $\mathrm{Zn} 2+$ in osteoblast behavior. Mater Sci Eng C Mater Biol Appl. 2021;118:111320. http://dx.doi.org/10.1016/j. msec.2020.111320. PMid:33254959.

9. Cruz MAE, Ruiz GCM, Faria AN, Zancanela DC, Pereira LS, Ciancaglini $\mathrm{P}$, et al. Calcium carbonate hybrid coating promotes the formation of biomimetic hydroxyapatite on titanium surfaces. Appl Surf Sci. 2016;370:459-68. http://dx.doi.org/10.1016/j. apsusc.2015.12.250.

10. Nakamura M, Hori N, Ando H, Namba S, Toyama T, Nishimiya $\mathrm{N}$, et al. Surface free energy predominates in cell adhesion to hydroxyapatite through wettability. Mater Sci Eng C Mater Biol Appl. 2016;62:283-92. http://dx.doi.org/10.1016/j. msec.2016.01.037. PMid:26952425.

11. Combes C, Rey C. Adsorption of proteins and calcium phosphate materials bioactivity. Biomaterials. 2002;23(13):2817-23. http:// dx.doi.org/10.1016/S0142-9612(02)00073-X. PMid:12059033.

12. Chen XB, Li YC, Hodgson PD, Wen C. The importance of particle size in porous titanium and nonporous counterparts for surface energy and its impact on apatite formation. Acta Biomater. 2009;5(6):2290-302. http://dx.doi.org/10.1016/j. actbio.2009.02.027. PMid:19307162.

13. Susana L, Campaci F, Santomaso AC. Wettability of mineral and metallic powders: applicability and limitations of sessile drop method and Washburn's technique. Powder Technol. 2012;226:68-77. http://dx.doi.org/10.1016/j.powtec.2012.04.016.

14. Kirdponpattara S, Phisalaphong M, Newby BM. Applicability of Washburn capillary rise for determining contact angles of powders/porous materials. J Colloid Interface Sci. 2013;397:16976. http://dx.doi.org/10.1016/j.jcis.2013.01.033. PMid:23484765.

15. Silva SPM, Oliveira JM. Cork powders wettability by the Washburn capillary rise method. Powder Technol. 2021;387:1621. http://dx.doi.org/10.1016/j.powtec.2021.04.005.

16. Tohry A, Dehghan R, Oliveira AV, Chelgani SC, Leal LS Fo. Enhanced Washburn Method (EWM): a comparative study for the contact angle measurement of powders. Adv Powder Technol. 2020;31(12):4665-71. http://dx.doi.org/10.1016/j. apt.2020.10.014.

17. Aktug SL, Durdu S, Aktas S, Yalcin E, Usta M. Characterization and investigation of in vitro properties of antibacterial copper deposited on bioactive ZrO 2 coatings on zirconium. Thin Solid Films. 2019;681:69-77. http://dx.doi.org/10.1016/j. tsf.2019.04.042. 
18. Gao X, Guo Z. Biomimetic superhydrophobic surfaces with transition metals and their oxides: a review. J Bionics Eng. 2017;14(3):401-39. http://dx.doi.org/10.1016/S16726529(16)60408-0.

19. Reinosa JJ, Romero JJ, Jaquotot P, Bengochea MA, Fernández JF. Copper based hydrophobic ceramic nanocoating. J Eur Ceram Soc. 2012;32(2):277-82. http://dx.doi.org/10.1016/j. jeurceramsoc.2011.08.013.

20. Li J, Zhai D, Lv F, Yu Q, Ma H, Yin J, et al. Preparation of copper-containing bioactive glass/eggshell membrane nanocomposites for improving angiogenesis, antibacterial activity and wound healing. Acta Biomater. 2016;36:254-66. http://dx.doi.org/10.1016/j.actbio.2016.03.011. PMid:26965395.

21. Stähli C, James-Bhasin M, Hoppe A, Boccaccini AR, Nazhat SN. Effect of ion release from Cu-doped 45S5 Bioglass ${ }^{\circledR}$ on 3D endothelial cell morphogenesis. Acta Biomater. 2015;19:15-22. http://dx.doi.org/10.1016/j.actbio.2015.03.009. PMid:25770928.

22. Gupta N, Santhiya D, Murugavel S, Kumar A, Aditya A, Ganguli M, et al. Effects of transition metal ion dopants (Ag, $\mathrm{Cu}$ and $\mathrm{Fe}$ ) on the structural, mechanical and antibacterial properties of bioactive glass. Colloids Surf A Physicochem Eng Asp. 2018;538:393-403. http://dx.doi.org/10.1016/j. colsurfa.2017.11.023.

23. Santos SC, Spaniol KG, Chaves-Silva NE, Fernandes RPM, Tavares DS, Acchar W, et al. Copper-containing bioactive glass/PVA membranes for guided bone regeneration. J NonCryst Solids. 2021;557:120628. http://dx.doi.org/10.1016/j. jnoncrysol.2020.120628.

24. Kaur G, Pickrell G, Sriranganathan N, Kumar V, Homa D. Review and the state of the art: sol-gel and melt quenched bioactive glasses for tissue engineering. J Biomed Mater Res B Appl Biomater. 2016;104(6):1248-75. http://dx.doi.org/10.1002/ jbm.b.33443. PMid:26060931.

25. Sharma K, Kedia S, Singh AK, Basak CB, Chauhan AK, Basu $\mathrm{S}$, et al. Morphology and structural studies of laser treated 45S5 bioactive glass. J Non-Cryst Solids. 2016;440:43-8. http:// dx.doi.org/10.1016/j.jnoncrysol.2016.02.012.

26. Dollimore D, Spooner P, Turner A. The bet method of analysis of gas adsorption data and its relevance to the calculation of surface areas. Surf Technol. 1976;4(2):121-60. http://dx.doi. org/10.1016/0376-4583(76)90024-8.

27. Gelb LD, Gubbins KE. Pore size distributions in porous glasses: a computer simulation study. Langmuir. 1999;15(2):305-8. http://dx.doi.org/10.1021/la9808418.

28. Bohner M, Lemaitre J. Can bioactivity be tested in vitro with SBF solution? Biomaterials. 2009;30(12):2175-9. http://dx.doi. org/10.1016/j.biomaterials.2009.01.008. PMid:19176246.

29. Ji L, Shi B. A novel method for determining surface free energy of powders using Washburn's equation without calculating capillary factor and contact angle. Powder Technol. 2015;271:8892. http://dx.doi.org/10.1016/j.powtec.2014.11.002.

30. Van Oss C, Good R, Chaudhury M. The role of van der Waals forces and hydrogen bonds in "hydrophobic interactions" between biopolymers and low energy surfaces. J Colloid Interface Sci. 1986;111(2):378-90. http://dx.doi.org/10.1016/00219797(86)90041-X.

31. Van Oss CJ, Chaudhury MK, Good RJ. Interfacial Lifshitz-van der Waals and polar interactions in macroscopic systems. Chem Rev. 1988;88(6):927-41. http://dx.doi.org/10.1021/cr00088a006.

32. Todan L, Anghel EM, Osiceanu P, Turcu RVF, Atkinson I, Simon S, et al. Structural characterization of some sol-gel derived phosphosilicate glasses. J Mol Struct. 2015;1086:16171. http://dx.doi.org/10.1016/j.molstruc.2015.01.012.

33. Santos SC, Lazaro GS, dos Santos EA. Ordering in sol-gelderived bioactive glasses and its influence on the dissolution/ precipitation behavior in a complex culture medium. J NonCryst Solids. 2018;494:50-8. http://dx.doi.org/10.1016/j. jnoncrysol.2018.04.054.

34. Sulowska J, Waclawska I, Szumera M. Effect of copper addition on glass transition of silicate-phosphate glasses. J Therm Anal Calorim. 2012;109(2):705-10. http://dx.doi.org/10.1007/s10973012-2328-0.

36. Handke M, Sitarz M, Rokita M, Galuskin E. Vibrational spectra of phosphate - silicate biomaterials. J Mol Struct. 2003;651:3954. http://dx.doi.org/10.1016/S0022-2860(03)00099-1.

37. Agathopoulos S, Tulyaganov DU, Ventura JMG, Kannan S, Saranti A, Karakassides MA, et al. Structural analysis and devitrification of glasses based on the $\mathrm{CaO}-\mathrm{MgO}-\mathrm{SiO} 2$ system with B2O3, Na2O, CaF2and P2O5additives. J Non-Cryst Solids. 2006;352(4):322-8. http://dx.doi.org/10.1016/j. jnoncrysol.2005.12.003.

38. Bonino F, Damin A, Aina V, Miola M, Vernè E, Bretcanu $\mathrm{O}$ et al. In situ Raman study to monitor bioactive glasses reactivity. J Raman Spectrosc. 2008;39(2):260-4. http://dx.doi.org/10.1002/ jrs. 1860 .

39. Caldas S, Silva L, Araujo E. Nanocrystalline apatite formation on bioactive glass in a sol-gel synthesis. J Non-Cryst Solids. 2016;439:30-7. http://dx.doi.org/10.1016/j.jnoncrysol.2016.02.013.

40. Sułowska J, Wacławska I, Szumera M, Olejniczak Z. Characterization of thermally induced of crystalline phases in CuO-containing silicate-phosphate glasses. J Therm Anal Calorim. 2012;108(2):657-63. http://dx.doi.org/10.1007/ s10973-011-1988-5.

41. Lázaro GS, Santos SC, Resende CX, dos Santos EA. Individual and combined effects of the elements $\mathrm{Zn}, \mathrm{Mg}$ and $\mathrm{Sr}$ on the surface reactivity of a $\mathrm{SiO} 2 \cdot \mathrm{CaO} \cdot \mathrm{Na} 2 \mathrm{O} \cdot \mathrm{P} 2 \mathrm{O} 5$ bioglass system. J Non-Cryst Solids. 2014;386:19-28. http://dx.doi.org/10.1016/j. jnoncrysol.2013.11.038.

42. Oliveira PHH Jr, Santana LABAB, Ferreira NSS, SharifiAsl S, Shokuhfar T, Shahbazian-Yassar R, et al. Manganese behavior in hydroxyapatite crystals revealed by X-ray difference Fourier maps. Ceram Int. 2020;46(8):10585-97. http://dx.doi. org/10.1016/j.ceramint.2020.01.062.

43. Elliott JC. Structure and chemistry of the apatites and other calcium orthophosphates. London: Elsevier; 1994.

44. Miyajima H, Awadzi G, Ozer F, Mante FK. Effect of surface physico-chemico-biological modifications of titanium on critical and theoretical surface free energy. Appl Surf Sci. 2019;470:38694. http://dx.doi.org/10.1016/j.apsusc.2018.11.133.

45. Chen X, Zhu R, Gao H, Xu W, Xiao G, Chen C, et al. A high bioactive alkali-treated titanium surface induced by induction heat treatment. Surf Coat Tech. 2020;385:125362. http://dx.doi. org/10.1016/j.surfcoat.2020.125362.

46. Ding H, Pan H, Xu X, Tang R. Toward a detailed understanding of magnesium ions on hydroxyapatite crystallization inhibition. Cryst Growth Des. 2014;14(2):763-9. http://dx.doi.org/10.1021/ cg401619s.

47. Othmani M, Bachoua H, Ghandour Y, Aissa A, Debbabi M. Synthesis, characterization and catalytic properties of copper-substituted hydroxyapatite nanocrystals. Mater Res Bull. 2018;97:560-6. http://dx.doi.org/10.1016/j.materresbull.2017.09.056. 